\title{
Identifikasi Butir Beras Utuh Dan Butir Beras Patah Berdasarkan Perimeter Menggunakan Jaringan Syaraf Tiruan
}

\author{
Muhamad Rifqi ${ }^{1,}$ Retno Nugroho Whidhiasih 1, * \\ * Korespondensi: e-mail: retno.nw@gmail.com
}

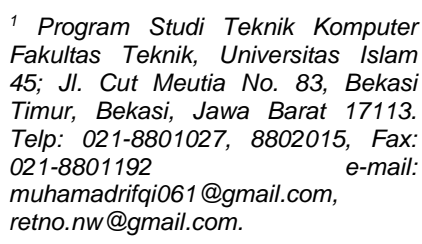

1 Program Studi Teknik Komputer Fakultas Teknik, Universitas Islam 45; Jl. Cut Meutia No. 83, Bekasi Timur, Bekasi, Jawa Barat 17113. Telp: 021-8801027, 8802015, Fax: 021-8801192 e-mail: muhamadrifai061@gmail.com, retno.nw@gmail.com.

Submitted: 9 Maret 2020 Revised: 30 Maret 2020 Accepted: 20 April 2020 Published: 20 Mei 2020

\section{Abstract}

Rice is a staple food for most Indonesian people. The prediction of rice production in 2016-2019 is estimated to reach 80.43 million tons, an increase of $2.57 \%$ over the next 4 years. The cause of broken rice occurs when separating rice grains from the grain, the grain is put into a scourer to remove the layer of aleuron that attaches to the rice. During rubbing, there is an emphasis on rice grains resulting in broken grains. Visual testing of rice so far is still using the manual method so there is concern that an error will still occur because of the limited human vision. Based on the above background the authors intend to develop research on identification of whole grain and broken rice grains based on the perimeter using artificial neural networks as a form of digital technology development (image processing) based on the quality of the Indonesian National Standard number (SNI 6128: 2015).

Keywords: Identification, Rice, Perimeter, Sobel, Artificial Neural Networks.

\section{Abstrak}

Beras merupakan makanan pokok bagi sebagian besar masyarakat Indonesia. Prediksi produksi padi pada tahun 2016-2019 diperkirakan akan mencapai 80,43 juta ton atau meningkat sebesar $2,57 \%$ dari selama periode 4 tahun kedepan. Penyebab beras patah terjadi pada saat pemisahan butir beras dari gabah, gabah tersebut dimasukkan ke dalam alat penyosoh untuk membuang lapisan aleuron yang menempel pada beras. Selama penyosohan terjadi penekanan terhadap butir beras sehingga terjadi butir patah. Pengujian beras secara visual selama ini masih menggunakan cara manual sehingga dikhawatirkan masih terjadi kesalahan karena terbatasnya pengelihatan manusia. Berdasarkan latar belakang diatas penulis bermaksud mengembangkan penelitian identifikasi butir beras utuh dan butir beras patah berdasarkan perimeter menggunakan jaringan syaraf tiruan sebagai bentuk dari pengembangan teknologi digital (pengolahan citra) berdasarkan mutu dari Standard Nasional Indonesia nomer (SNI 6128:2015).

Kata Kunci: Identifikasi, Beras, Perimeter, Sobel, Jaringan Syaraf Tiruan. 


\section{Pendahuluan}

Beras merupakan makanan pokok bagi sebagian besar masyarakat Indonesia. Konsumsi beras di Indonesia semakin meningkat setiap tahunnya seiiring dengan meningkatnya jumlah penduduk Indonesia. Prediksi produksi padi pada tahun 2016-2019 diperkirakan akan mencapai 80,43 juta ton atau meningkat sebesar 2,57\% dari selama periode 4 tahun kedepan. Produksi tersebut akan dicapai oleh pencapaian produktivitas padi yang diperkirakan akan mencapai 5,40 ton per hektar atau meningkat $0,91 \%$ per tahun, sementara peningkatan luas panen diperkirakan akan mencapai 1,65\% atau mencapai luas sebesar 14,89 juta hektar (Pusat Data dan Sistem Informasi Pertanian, 2015).

Namun semakin bertambahnya penduduk di Indonesia, kebutuhan beras juga semakin bertambah, harga beras yang beredar di pasaran terus melonjak sehingga banyak pedagang yang menjual beras dengan kualitas yang kurang baik. Sayangnya masih banyak konsumen yang belum tahu bagaimana membedakan beras dengan kualitas yang baik atau kualitas rendah. Oleh karena itu, diperlukan standar kualitas mutu yang harus ditetapkan oleh pihak gudang distributor beras (Nurcahyani dan Ristu, 2015).

Proses pengujian yang di tetapkan dari pihak Bulog terdapat dua tahap, yaitu uji visual dan uji laboratorium. Uji kualitas beras secara visual dapat dilihat dari keutuhan, kebersihan, dan putihnya beras. Penyebab beras patah terjadi pada saat pemisahan butir beras dari gabah, gabah tersebut dimasukkan ke dalam alat penyosoh untuk membuang lapisan aleuron yang menempel pada beras. Selama penyosohan terjadi penekanan terhadap butir beras sehingga terjadi butir patah. Pengujian beras secara visual selama ini masih menggunakan cara manual sehingga dikhawatirkan masih terjadi kesalahan karena terbatasnya pengelihatan manusia. Oleh karena itu, diperlukan sebuah sistem untuk mengefisienkan pengujian beras secara visual (Nurcahyani dan Ristu, 2015).

Banyak Penelitian yang dilakukan untuk mengidentifikasi kualitas beras yang baik dan beras yang rusak. Identifikasi Beras Berdasarkan Warna Menggunakan Metode (Adaptive Neuro Fuzzy Inference System) dengan pengolahan citra yang berdasarkan perpaduan dari ruang warna HSV ,L a*b* menjadi $S$ $a^{*} b^{*}$ untuk identifikasi beras IR 64 yang baik dan beras IR 64 yang rusak menghasilkan akurasi 80\% menggunakan nilai variabel La*b* dan akurasi 90\% menggunakan nilai Sa*b* (Alfianto, 2017).

Identifikasi beras menggunakan metode susan detection dan neurofuzzy untuk mengidentifikasi komponen kualitas beras. Komponen yang diuji adalah beras utuh, beras patah dan butir menir. Tingkat keberhasilan pengujian panjang butir beras adalah $94.22 \%$ dari keseluruhan sample, dengan tingkat kesalahan $5,78 \%$ dalam pendeteksian bentuk beras ( Amal, 2017).

Penelitian juga dilakukan untuk pemutuan biji kopi arabika, sampel yang digunakan dalam penelitian ini adalah kopi arabika yaitu pada kelas mutu A, B, C, dan reject (RJ). Parameter yang digunakan yaitu: area, tinggi, lebar, perimeter, area cacat, indeks warna merah ( $r$ ) dan indeks warna hijau (g) dengan menggunakan metode jaringan syaraf tiruan. Akurasi pemutuan sekitar $81,10 \%$ dengan akurasi pada masing-masing kelas mutu A, B, C dan RJ berturut-turut sebesar 83,13\%, 70,63\%, 75,00\%, dan 95,63\% (Risamasu, 2017).

Berdasarkan latar belakang diatas penulis bermaksud mengembangkan penelitian identifikasi butir beras utuh dan butir beras patah berdasarkan perimeter menggunakan jaringan syaraf tiruan sebagai bentuk dari pengembangan teknologi digital (pengolahan citra) berdasarkan mutu dari Standard Nasional Indonesia nomer (SNI 6128:2015). 


\section{Metode Penelitian}

Bahan yang digunakan sebanyak 100 butir beras IR64 terdiri dari 50 butir beras utuh dan 50 butir beras patah. Butir beras didapat dari pertanian yang telah melalui proses pemilihan sesuai Standard Nasional Indonesia nomer (SNI 6128:2015).

Alat yang digunakan dalam penelitian ini terdiri dari 2 perangkat, yaitu: Laptop ASUS X455D RAM 4GB DDR 3 Processor AMD A10 3,0 Ghz, HDD 1 TB, Kamera DSLR Canon Eos 600d, Photobox. Perangkat lunak (software) yang digunakan terdiri dari: Sistem Operasi Windows 10, Matlab R2014b Trial Edition, Photoshop CS6 Portable.

Dalam melakukan tugas akhir ini, penulis melakukan beberapa tahapan seperti pada gambar 1.

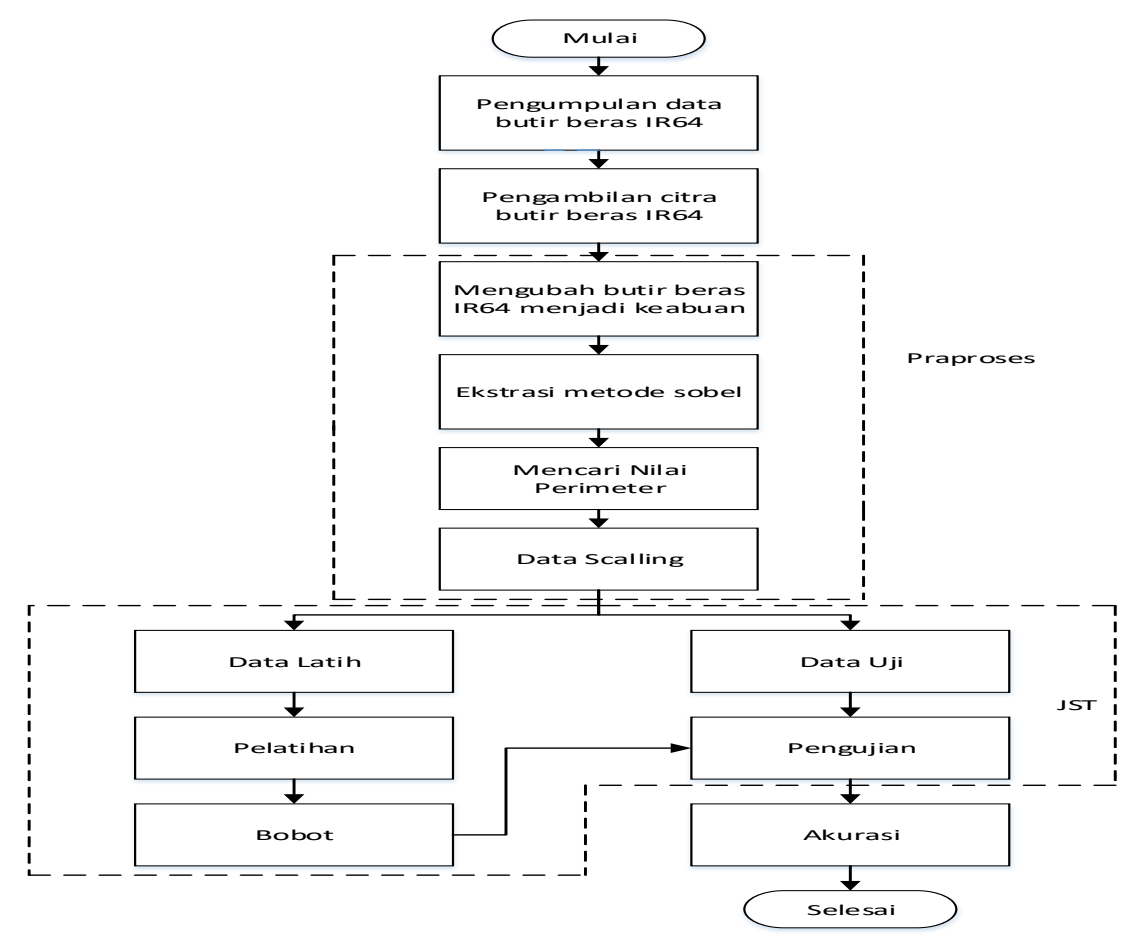

Sumber: Hasil Penelitian (2020)

Gambar 1. Tahapan penelitian

\section{Hasil dan Pembahasan}

\section{Pengumpulan Data}

Pengumpulan data butir beras IR 64 di dapat dari pertanian Desa Sumberjaya kecamatan Tambun Selatan Kabupaten Bekasi sebanyak 50 butir beras utuh dan 50 butir beras patah sehingga jumlah keseluruhan 100 butir beras.

\section{Pengambilan Citra}

Pengambilan citra butir beras IR 64 dilakukan dengan menggunakan kamera DSLR Canon Eos $600 \mathrm{~d}$ dengan jarak foto $+10 \mathrm{~cm}$ dengan menggunakan studio foto mini dialasi background kertas berwarna hitam dan menggunakan 3 lampu 12 watt yang dipasang pada bagian kiri, kanan dan atas seperti pada gambar 2. 


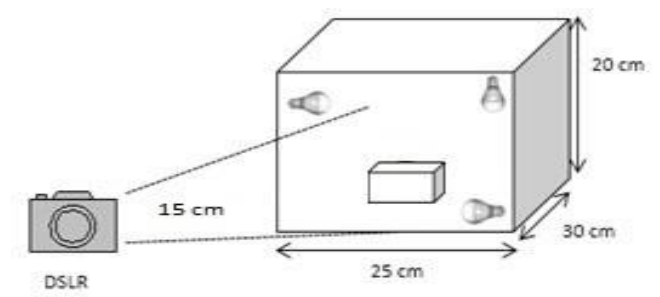

Sumber: Hasil Penelitian (2020)

Gambar 2. Proses Pengambilan Citra

\section{Praproses}

a) Mengubah Citra RGB Menjadi Keabuan

Tahap mengubah citra butir beras IR 64 kedalam citra keabuan yaitu nilai yang diambil adalah nilai rata-rata dari keseluruhan piksel. Untuk menghitung rata-rata nilai $R, G, B$ menggunakan persamaan (11) sampai (13).

$$
\begin{aligned}
& R=\frac{r}{r+g+b} \ldots \ldots \ldots \ldots \ldots \ldots \ldots(11) \quad G=\frac{g}{r+g+b} \\
& B=\frac{b}{r+g+b} \ldots \ldots \ldots \ldots \ldots \ldots \ldots \ldots \ldots(13)
\end{aligned}
$$

Mengubah nilai RGB menjadi nilai grayscale menggunakan persamaan.

Grayscale $=0,2989$ * $R+0,5870$ * $G+0,1140$ * $B$

b) Ekstrasi Metode Sobel

Menghitung nilai gradient masing-masing pixel yaitu dengan cara mengurangi baris ke-3 dengan baris ke-1 untuk posisi koordinat $\mathrm{x}$ dan kolom ke-3 dengan kolom ke-1 untuk posisi koordinat $\mathrm{y}$ menggunakan persamaan (15),(16) dan (17).

$$
\begin{aligned}
& \mathrm{Gx}=(\mathrm{a} 6+2 \mathrm{a} 5+\mathrm{a} 4)-(\mathrm{a} 0+2 \mathrm{a} 1+\mathrm{a} 2) . \\
& \mathrm{Gy}=(\mathrm{a} 2+2 \mathrm{a} 3+\mathrm{a} 4)-(\mathrm{a} 0+2 \mathrm{a} 7+\mathrm{a} 6) \ldots \ldots \ldots
\end{aligned}
$$

(16) Gradient $(x, y)=\sqrt{G x^{2}+G y^{2}}$

Nilai gradient yang telah dihasilkan sudah dapat digunakan untuk mendeteksi tepi, namun citra yang dihasilkan masih memungkinkan terdapat gangguan. Sehingga untuk lebih terlihat perbedaan tepi pada citra, digunakan nilai threshold yang ditentukan. Nilai threshold ini adalah nilai minimal yang diijinkan untuk nilai masing-masing pixel. Sehingga apabila nilai pixel hasil gradient kurang dari threshold maka nilai akan diubah menjadi sama dengan threshold.

c) Mencari Nilai Perimeter

Nilai perimeter didapat dengan menghitung banyaknya piksel-piksel yang berada pada perbatasan dari obyek yang dihasilkan dari ekstrasi metode sobel. Menghitung nilai perimeter menggunakan persamaan (18).

Perimeter $=\mathrm{Ne}+\mathrm{No} \sqrt{2}$

d) Data Scalling

Hasil dari ekstrasi nilai perimeter selanjutnya discalling, untuk menghitung nilai yang sudah discalling menggunakan persamaan (19). 


$$
\text { newdata }\left(\frac{(\text { data }-\min ):(0.9-0.1)}{(\max -\min )+0.1}\right)
$$

Newdata $=$ data hasil scalling

$\min =$ nilai minimum dari data per kolom

max = nilai maximum dari data per kolom

newmin = adalah batas minimum yang kita berikan, pada penelitian ini menggunakan nilai minimum 0.1

newmax = adalah batas maksimum yang kita berikan, pada penelitian ini menggunakan nilai maksimum 0.9

e) Pembagian Data Pelatihan dan Data Pengujian

Data pelatihan berjumlah 80 butir beras terdiri dari 40 butir beras utuh dan 40 butir beras patah. Data pengujian berjumlah dari 20 butir beras terdiri dari 10 butir beras utuh dan 10 butir beras patah.

\section{Jaringan Syaraf Tiruan}

JST harus memiliki input dan output, dalam identifikasi ini input yang digunakan adalah nilai perimeter dan output yang digunakan butir beras utuh dan butir beras patah seperti pada table 1 .

Tabel 1. Output yang digunakan

\begin{tabular}{lll}
\hline Kode & kualitas mutu & Keterangan \\
\hline 1 & Utuh & butir beras yang tidak ada patah sama sekali \\
\hline 2 & Patah & butir beras dengan ukuran lebih besar dari \\
& & $\begin{array}{l}0,2 \text { sampai dengan lebih kecil } 0,8 \text { bagian } \\
\text { dari butir beras utuh }\end{array}$ \\
\hline
\end{tabular}

Sumber: Hasil Penelitian (2020)

\section{1) Tahap Pelatihan}

Parameter pada tahap pelatihan terdapat pada tabel 2. Setiap neuron dicoba sebanyak 30 kali perulangan. Jika kesalahan lebih kecil atau sama dengan MSE yang ditentukan atau jika mencapai batas epoch pelatihan akan dihentikan.

Tabel 2. Parameter Pelatihan

\begin{tabular}{|c|c|}
\hline \multicolumn{2}{|c|}{ Parameter Pelatihan } \\
\hline Input & Perimeter \\
\hline Output & Utuh,Patah \\
\hline Maksimum Epoch & 2500 Epoch \\
\hline Laju Pembelajaran (Learning Rate) & 0.01 \\
\hline Nilai MSE (error) & 0.0001 \\
\hline Jumlah Variasi Neuron & $2,5,10,15,20$ \\
\hline
\end{tabular}

\section{2) Tahap Pengujian}

Tahap untuk melalukakan pengujian bobot paling optimal menggunakan data testing. Bobot paling optimal dihasilkan dari tahap pelatihan. Pengujian menghasilkan identifikasi beras utuh dan beras patah dalam bentuk akurasi.

\section{3) Accuracy}

Accuracy (Akurasi) adalah perbandingan kasus yang diidentifikasi benar dengan jumlah semua kasus menggunakan rumus pada persamaan (20). 


$$
A C=\frac{a+d}{a+b+c+d} .
$$

Akurasi ditampilkan dalam bentuk matriks confusion yang disajikan pada tabel 3 .

Tabel 3. Matriks Confusion

\begin{tabular}{lllll}
\hline & \multicolumn{3}{c}{$\begin{array}{c}\text { Predicted } \\
\text { Negative Positive }\end{array}$} \\
\hline \multirow{2}{*}{ Actual } & Negative & a & b \\
\cline { 2 - 4 } & & Positive & c & d \\
\hline
\end{tabular}

Sumber: Hasil Penelitian (2020)

\section{Keterangan:}

a. jika hasil prediksi negatif dan data sebenarnya negatif.

b. jika hasil prediksi positif sedangkan nilai sebenarnya negatif

c. jika hasil prediksi negatif sedangkan nilai sebenarnya positif.

d. jika hasil prediksi positif dan nilai sebenarnya positif

\section{Hasil dan Pembahasan}

\section{1 Hasil}

\section{Pengambilan Citra}

Pengambilan citra beras IR64 dilakukan dengan memfoto butir beras IR64 dalam sebuah kotak studio foto dengan menggunakan background berwarna hitam dan menggunakan 3 buah lampu 12 watt yang terpasang pada sisi kiri, kanan dan atas pada kotak studio foto, dengan jarak pengambilan foto $\pm 15 \mathrm{~cm}$.

\section{Praproses}

\section{a. Mengubah Citra Beras IR64 Menjadi Keabuan}

Merubah citra beras IR64 menjadi keabuan dengan cara mencari nilai yang terdapat pada masingmasing komponen R,G,B kemudian menjumlahkan semua nilai yang terdapat pada masing-masing komponen $R, G, B$ tersebut, setelah itu membagi hasil dari penjumlahan tersebut dengan jumlah piklsel yang terdapat dalam citra.

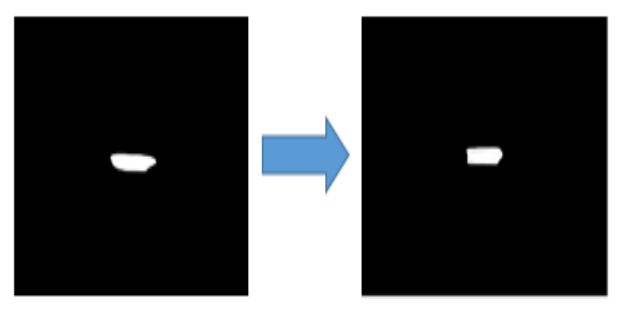

Sumber: Hasil Penelitian (2020)

Gambar 3. Mengubah citra asli menjadi keabuan

\section{b. Ekstrasi Metode Sobel}

Ekstrasi sobel digunakan untuk mendapatkan garis tepi dari citra butir beras IR64. Kelebihan dari metode sobel ini adalah mengurangi noise sebelum melakukan perhitungan deteksi tepi. 

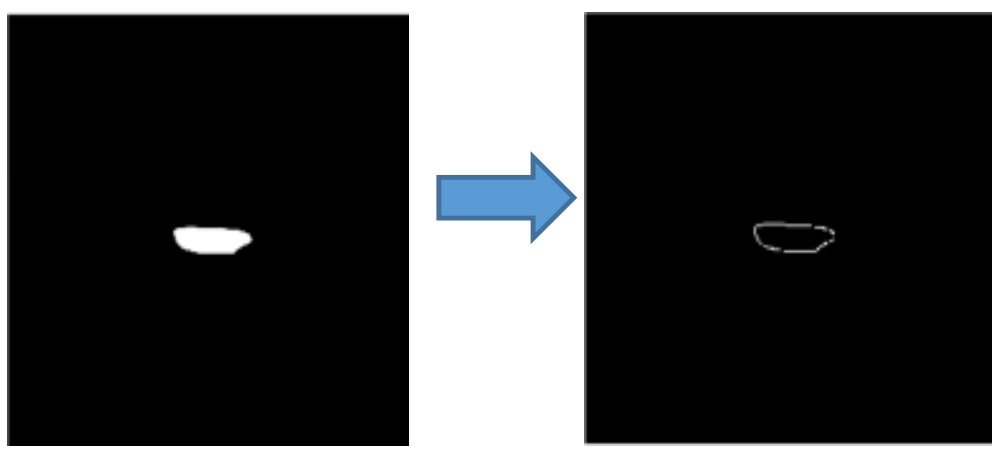

Sumber: Hasil Penelitian (2020)

Gambar 4. Ekstrasi metode sobel

\section{c. Mencari Nilai Perimeter}

Nilai perimeter didapat dengan menghitung banyaknya piksel-piksel yang berada pada perbatasan dari obyek yang dihasilkan dari ekstrasi metode sobel. Nilai perimeter yang didapat 295395.

\section{d. Data Scalling}

Nilai perimeter didapat dengan menghitung banyaknya piksel-piksel yang berada pada perbatasan dari obyek yang dihasilkan dari ekstrasi metode sobel. Nilai perimeter yang sudah discalling 0.240296.

\section{e. Pembagian Data}

Identifikasi butir beras utuh dan butir beras patah ini menggunakan 100 butir beras IR64, data yang terdiri dari 50 butir beras utuh dan 50 butir beras patah. Data yang digunakan untuk training berjumlah 80 terdiri dari 40 butir beras utuh dan 40 butir beras patah. Data yang digunakan untuk testing berjumlah 20 terdiri 10 butir beras utuh dan 10 butir beras patah.

\section{Jaringan Syaraf Tiruan Backpropagation}

Tahap identifikasi menggunakan JST mempunyai 2 tahapan yaitu tahap pelatihan dan tahap pengujian. Tujuan dari tahapan pelatihan yaitu untuk mendapatkan bobot yang optimal dan tujuan dari tahap pengujian untuk menguji kemampuan pengenalan

a. Tahap Pelatihan

Tujuan dari tahapan pelatihan yaitu untuk mendapatkan bobot yang optimal. Pelatihan masing-masing tiap variasi neuron dilakukan dengan 30 kali perulangan. Hasil pelatihan variasi neuron disajikan pada tabel 4.

Tabel 4. Hasil pelatihan masing-masing neuron

\begin{tabular}{cccc}
\hline $\begin{array}{c}\text { Jumlah } \\
\text { Neuron }\end{array}$ & Epoch & Waktu & MSE \\
\hline 2 & 2048 & $0: 00: 28$ & 0.0265 \\
\hline 5 & 775 & $0: 00: 13$ & 0.000635 \\
\hline 10 & 284 & $0: 00: 03$ & 0.000527 \\
\hline $\mathbf{1 5}$ & $\mathbf{2 7 2}$ & $\mathbf{0 : 0 0 : 0 4}$ & $\mathbf{0 . 0 0 0 4 9 4}$ \\
\hline 20 & 192 & $0: 00: 02$ & 0.000877 \\
\hline
\end{tabular}

Sumber: Hasil Penelitian (2020)

Hasil dari pelatihan tiap variasi neuron yang terbaik dihasilkan dari variasi neuron 15 pada hidden layer dengan nilai MSE 0.000494 pada Epoch 272 dengan waktu 4 detik. Bobot paling optimal yang didapat dari hasil pelatihan tersebut terdapat pada tabel 5 . 


\begin{tabular}{|c|c|c|c|}
\hline Bobot Bias Akhir Input & Bobot Bias Akhir Lapisan & Bobot Akhir Input & Bobot Akhir Lapisan \\
\hline-47.6693 & & 53.997 & 0.0014949 \\
\hline-43.5623 & & 54.9367 & 0.000010992 \\
\hline 40.3535 & & -55.0804 & 0.000099471 \\
\hline-36.1296 & & 55.8623 & -0.0028817 \\
\hline-30.1619 & & 58.0349 & -0.90257 \\
\hline 42.1293 & & -85.0562 & 5.0249 \\
\hline 49.0616 & & -103.8336 & 19.9716 \\
\hline-18.3088 & 1.5004 & 39.7477 & 59.2665 \\
\hline-42.1775 & & 92.0015 & 30.54 \\
\hline-41.4639 & & 94.1773 & -46.7907 \\
\hline 31.6996 & & -75.7419 & 16.6115 \\
\hline-14.6759 & & 54.644 & -0.0023716 \\
\hline-10.582 & & 54.9436 & 0.0003216 \\
\hline 7.5494 & & -54.951 & 0.0012808 \\
\hline-4.5867 & & 54.9485 & 0.0022439 \\
\hline
\end{tabular}

Sumber: Hasil Penelitian (2020)

b. Tahap Pengujian

Pada tahapan pengujian bobot yang paling optimal didapatkan dari hasil pelatihan menggunakan 15 neuron pada hidden layer diuji menggunakan data testing, data testing terdapat pada lampiran 6 . Dari hasil pengujian butir beras didapatkan hasil, butir beras utuh yang diprediksi sebagai butir beras utuh oleh JST sebanyak 10, sedangkan butir beras utuh yang diprediksi sebagai butir beras patah oleh JST sebanyak 0 sehingga ketepatan pengenalan (akurasi) JST butir beras utuh sebanyak 100\%. Butir beras patah yang diprediksi sebagai butir beras utuh oleh JST sebanyak 1, sedangkan butir beras patah yang diprediksi sebagai butir patah oleh JST sebanyak 9 sehingga ketepatan pengenalan (akurasi) JST butir beras patah sebanyak $90 \%$. Hasil pengujian disajikan pada tabel tabel 6 .

Tabel 6. Hasil Pengujian

\begin{tabular}{ccc}
\hline Aktual & \multicolumn{2}{c}{ Prediksi JST } \\
\hline & Utuh & Patah \\
\hline Utuh & 10 & 0 \\
\hline Patah & 1 & 9 \\
\hline
\end{tabular}

Sumber: Hasil Penelitian (2020)

Ketepatan pengenalan (akurasi) rata-rata dari hasil pengujian butir beras utuh dan butir beras patah berdasarkan perimeter sebesar $95 \%$.

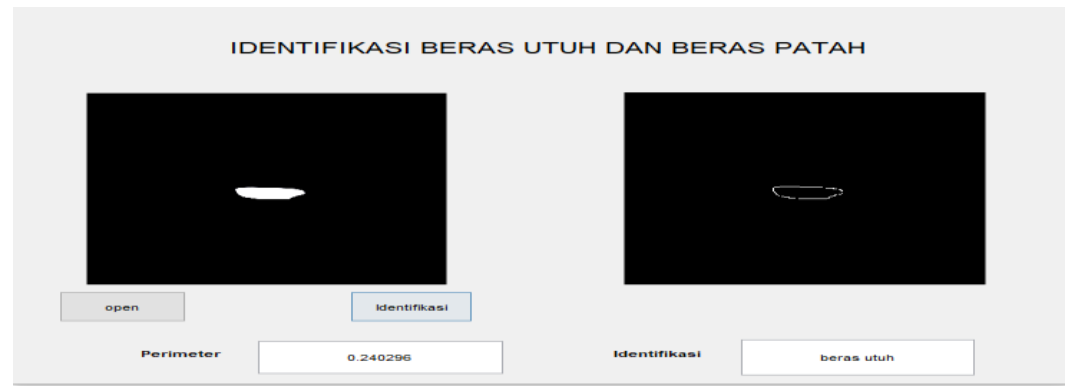

Sumber: Hasil Penelitian (2020)

Gambar 5 Graficial User Interfac 
c. Graficial User Interface (GUI)

Graficial User Interface dibangun untuk identifikasi beras utuh dan beras patah menggunakan jaringan syaraf tiruan menjadi lebih interaktif terhadap pengguna seperti pada gambar 5 .

\subsection{Pembahasan}

Pada tahap pelatihan dilakukan dengan beberapa jumlah variasi neruon yaitu 2,5,10,15,20 pada hidden layer dengan parameter 2500 epoch, Learning Rate 0.01 dan nilai MSE (error) 0.0001 dengan 30 kali perulangan. Dalam pengujian variasi neuron 2 pada hidden layer mendapatkan ketepatan pengenalan (akurasi) JST rata-rata 95\% pada epoch 2048, MSE 0.0265 dengan waktu 28 detik. Pengujian variasi neuron 5 pada hidden layer mendapatkan mendapatkan ketepatan pengenalan (akurasi) JST rata-rata 95\% pada epoch 775, MSE 0.000635 dengan waktu 13 detik. Pengujian variasi neuron 10 pada hidden layer mendapatkan mendapatkan ketepatan pengenalan (akurasi) JST rata-rata 95\% pada epoch 284, MSE 0.000527 dengan waktu 3 detik. Pengujian variasi neuron 15 pada hidden layer mendapatkan mendapatkan ketepatan pengenalan (akurasi) JST rata-rata 95\% pada epoch 272, MSE 0.000494 dengan waktu 4 detik. Pengujian variasi neuron 20 pada hidden layer mendapatkan ketepatan pengenalan (akurasi) JST rata-rata 95\% pada epoch 192, dengan waktu 2 detik. Grafik akurasi, waktu dan MSE dari tiap variasi neuron disajikan pada gambar 6 sampai gambar 7.
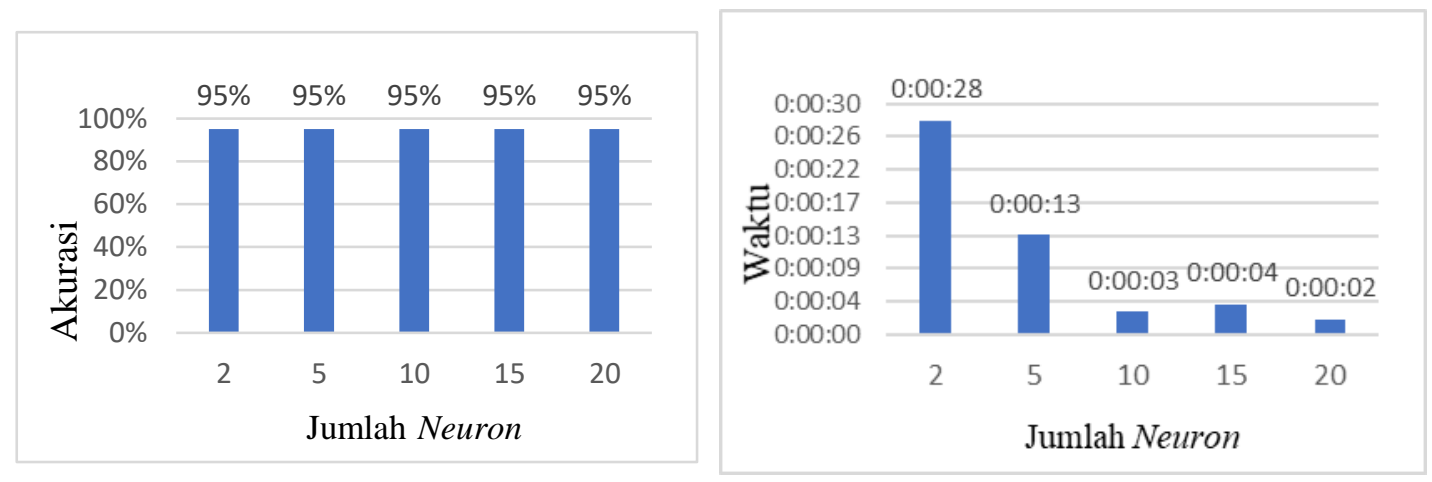

Sumber: Hasil Penelitian (2020)

Gambar 6 Akurasi pada setiap neuron dan Waktu pada setiap neuron

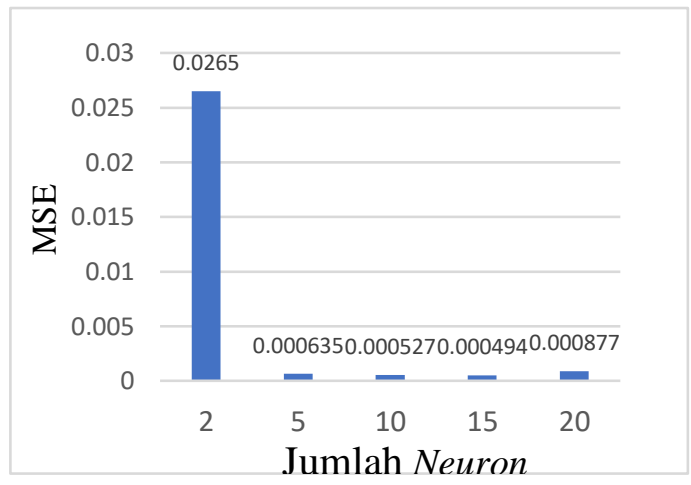

Sumber: Hasil Penelitian (2020)

Gambar 7. MSE pada setiap neuron 
Hasil pengenalan terbaik dari semua variasi neuron pada hidden layer yang dicobakan didapat pada variasi neuron 15 mendapatkan mendapatkan ketepatan pengenalan (akurasi) rata-rata 95\% pada epoch 272, MSE 0.000494 dengan waktu 4 detik.

\section{Kesimpulan}

Berdasarkan hasil percobaan identifikasi butir beras utuh dan butir beras patah berdasarkan perimeter menggunakan jaringan syaraf tiruan maka dapat ditarik kesimpulan sebagai berikut: 1) Identifikasi butir beras utuh dan butir beras patah berdasarkan perimeter menggunakan Jaringan Syaraf Tiruan dicoba menggunakan beberapa variasi neuron pada hidden layer yaitu 2,5,10,15 dan 20 neuron. Pelatihan masing-masing variasi neuron dilakukan dengan 30 kali perulangan. 2) Bobot paling optimal didapat pada variasi neuron 15 pada hidden layer dengan nilai MSE 0.000494 pada epoch 272 dengan waktu 4 detik. 3) Ketepatan pengenalan (akurasi) JST dari butir beras IR64 yaitu butir beras utuh sebanyak 100\%, butir beras patah sebanyak 90\%. Pengenalan (akurasi) JST ratarata dari hasil butir beras utuh dan butir beras patah berdasarkan perimeter sebesar $95 \%$. Saran dari penelitian ini adalah pengcapturan citra sebaiknya dilakukan dengan kamera beresolusi tinggi dengan pengambilan jarak foto yang lebih dekat untuk menjaga ketajaman foto setelah proses crop untuk meningkatkan akurasi.

\section{Daftar Pustaka}

Alfianto, M.G. 2017. Identifikasi Beras Berdasarkan Warna Menggunakan Adaptive Neuro Fuzzy Inference System, Jurnal Penelitian IImu Komputer, Sistem Embedded \& Logic. 5(2): 51-59 (2017).

Amal, I. 2017. Pengolahan Citra Digital Menggunakan Metode Susan Detection Dan Neurofuzzy Untuk Identifikasi Komponen Kualitas Beras. Skripsi. Universitas Negeri Yogyakarta.

Amin, S. 2012. Sistem Deteksi Dini Hama Wereng Batang Coklat Menggunakan Jaringan Syaraf Tiruan Backpropagation. Skripsi. Semarang: FMIPA Universitas Negeri Semarang.

Harjoko, A. 2014. "Pemrosesan Citra Digital untuk Klasifikasi Mutu Buah Pisang Menggunakan Jaringan Saraf Tiruan". Skripsi. Yogyakarta: Universitas Gajah Mada (UGM).

Kadir Abdul \& Susanto Adhi. 2013 Teori dan Aplikasi Pengolahan Citra. Yogyakarta: ANDI.

Madi, S. C. Y. 2010. "Pemutan Biji Kopi Dengan Menggunakan Pengolahan Citra (Image Processing)". Skripsi. Bogor: Institut Pertanian Bogor (IPB).

Risamasu, D.E.P.2017. "Identifikasi Bentuk Biji Kopi Menggunakan Deskriptor Bentuk Dasar Dan Jaringan Syaraf Tiruan". Skripsi Yogyakarta: Universitas Sanata Dharma.

Siang, J.J. 2009. Jaringan Syaraf Tiruan dan Pemrogramannya Menggunakan MATLAB. Yogyakarta: ANDI.

Zalukhu, A. 2016. Implementasi Metode Canny dan Sobel Untuk Mendeteksi Tepi Citra. Skripsi. Medan: STMIK Budi Darma Medan. 